\title{
FAKTOR-FAKTOR YANG MEMPENGARUHI PRODUKTIFITAS KARYAWAN DEPARTEMEN STAMPING PERUSAHAAN DALAM INDUSTRI PENGOLAHAN KENDARAAN BERMOTOR
}

\author{
RR. NIKEN PURBASARI \\ R. WASISTO RUSWIDIONO \\ FARADILA Y. ARDINI \\ Trisakti School of Management, JI. Kyai Tapa No. 20, Jakarta 11440, Indonesia \\ npurbasari@stietrisakti.ac.id, wasisto@stietrisakti.ac.id
}

\begin{abstract}
The success of manufacturing companies managing employee productivity will determine the company's continuity in maintaining its position in the manufacturing industry. This study aims to determine the effect of compensation, work discipline and intrinsic motivation on employee productivity of the stamping department of PT $\mathrm{MXX}$, which is one of the major companies in the motor vehicle processing industry in Indonesia. Using saturated sampling techniques, the total population in this study was 118 employees. The analytical method used is multiple linear regression. The results of this study indicate that only compensation that affects employee productivity, work discipline and intrinsic motivation does not affect the productivity of PT MXX employees which may be caused by the characteristics of the work characteristics of the stamping department and the characteristics of the population dominated by male sex employees with young adults who emphasize the meaning the importance of the compensation they receive as a result of their work productivity.
\end{abstract}

Keywords: Kompensasi, disiplin kerja, motivasi intrinsik, dan produktifitas karyawan

\begin{abstract}
Abstrak: Keberhasilan perusahaan manufakturing mengelola produktifitas karyawan akan menentukan kontinyuitas perusahaan mempertahankan posisinya dalam industri manufaktur. Penelitian ini bertujuan untuk mengetahui pengaruh kompensasi, disiplin kerja dan motivasi intrinsik terhadap produktivitas karyawan departemen stamping PT MXX yang merupakan salah satu perusahaan besar dalam industri pengolahan kendaraan bermotor di Indonesia. Menggunakan teknik sampling jenuh, jumlah populasi dalam penelitian ini adalah 118 karyawan. Metode analisis yang digunakan adalah regresi linier berganda. Hasil penelitian ini menunjukan bahwa hanya kompensasi yang memengaruhi produktivitas karyawan, disiplin dan motivasi intrinsik tidak berpengaruh terhadap produktivitas karyawan PT MXX yang mungkin disebabkan oleh karakteristik karakteristik pekerjaan pada departemen stamping dan karakteristik dari populasi yang didominasi karyawan berjenis kelamin pria dengan usia dewasa muda yang menekankan arti pentingnya kompensasi yang mereka terima sebagai hasil produktifitas kerja mereka.
\end{abstract}

Kata kunci: Kompensasi, disiplin, motivasi intrinsik, dan produktifitas karyawan

\section{PENDAHULUAN}

Industri Manufaktur menjadi salah satu sektor andalan yang mendorong pertumbuhan ekonomi Indonesia melalui pertumbuhan PDB. Berdasarkan besaran Produk Domestik Bruto (PDB) atas dasar harga berlaku triwulan I-2019 Perekonomian 
Indonesia telah mencapai Rp 3,782,4 triliun (Biro Pusat Statistik-BPS, 2019). Industri pengolahan menjadi sektor yang paling besar memberikan kontribusi pada PDB. Industri pengolahan kendaraan bermotor menyumbang nilai ekspors sebesar 3.51 persen dari total nilai ekspor industri pengolahan 73.24 persen (BPS, 2019). Data tersebut menunjukkan bahwa industry pengolahan khususnya kendaraan bermotor memiliki peran yang cukup berarti dalam mendorong pertumbuhan ekonomi di Indonesia. Permasalahan yang menarik untuk diteliti adalah bagaimana perusahaan yang berada dalam industry pengolahan kendaraan bermotor seperti PT MXX mampu menjaga produktifitas karyawannya agar perusahaan dapat mempertahankan kinerja perusahaan sehingga mampu memberikan kontribusi pada pertumbuhan perekonomian Indonesia secara berkelanjutan.

Produktivitas menjadi bagian penting dalam kinerja, sehingga tugas manajemen untuk mengembangkan sistem pengukuran, evaluasi, kontrol, dan usaha untuk peningkatan kriteria kinerja ini menjadi krusial (Sink, Tuttle, \& Devries 1984). Produktifitas karyawan menunjukkan kinerja perusahaan. Karyawan dengan produktitiftas yang tinggi akan mendukung upaya perusahaan mencapai kinerja unggul. Karyawan perusahaan menjadi faktor penggerak dinamis yang akan menentukan operasional perusahaan berjalan efektif dan efisien. Produktifitas karyawan menentukan keberhasilan perusahaan dalam jangka panjang. Berbagai studi menunjukkan banyak faktor yang dapat mempengaruhi produktitiftas karyawan, namun demikian penelitian ini dibatasi pada untuk mengetahui pengaruh kompensasi, disiplin kerja dan motivasi intrinsik terhadap produktitiftas karyawan departemen stamping PT MXX.

\section{Produktivitas Karyawan}

Produktivitas

merupakan

permasalahan dari sisi input dan output, kriteria yang menguji hubungan antara apa yang keluar dan apa yang masuk. Dalam hal ini, produktifitas mengintegrasikan efektivitas, efisiensi, dan kualitas ke dalam satu dimensi produktifitas karyawan (Sink et al., 1984). Produktitiftas juga merupakan komponen dari persamaan kinerja tugas karyawan yang mencakup relevansi, kuantitas, dan kualitas hasil yang terukur dalam target atau capaian kerja. Kinerja tugas berhubungan dengan mengubah bahan mentah menjadi barang dan jasa yang khusus untuk pekerjaan, keterampilan teknis inti (Makki \& Abid 2017). Beberapa faktor dapat mempengaruhi produktifitas karyawan, seperti kompensasi, disiplin kerja dan motivasi instrinsik. Selain motivator intrinsik yang penting untuk produktifitas karyawan, motivator ekstrinsik atau kompensasi sebagai penghargaan seperti gaji juga memiliki peran sentral dalam menjelaskan mengapa individu produktif di tempat kerja (Samnani dan Singh, 2014). Elqadri dalam studinya menyimpulkan bahwa dengan disiplin kerja dan motivasi yang baik, maka produktivitas karyawan jadi jauh lebih tinggi(Elqadri, Wardoyo, \& -, 2015).

\section{Kompensasi}

Kompensasi mengacu pada semua pembayaran dalam bentuk moneter dan barang atau komoditas yang digunakan sebagai pengganti uang untuk penghargaan kepada karyawan (Daft 2012). Kompensasi dapat mencakup berbagai jenis imbalan dan tunjangan seperti upah dan gaji berbasis, pembayaran insentif, tunjangan dan layanan lainnya (Robbins \& Coulter 2009). Karyawan dapat menilai perasaan puas atau tidak puas atas system kompensasi yang perusahaan berikan. Kepuasan atas pembayaran atau gaji yang diterima mewakili suatu sikap yang mempengaruhi perasaan positif atau 
negative individu terhadap upah yang mereka terima (Dulebohn \& Werling 2007). Ada beberapa penjelasan teoritis untuk hubungan positif antara sistem kompensasi, peningkatan kinerja dan produktivitas karyawan (Samnani \& Singh, 2014). Temuan menunjukkan bahwa peningkatan kinerja dapat dijelaskan dengan kompensasi (Purbasari \& Septian 2017), artinya jika produktifitas merupakan elemen dari kinerja maka mungkin saja kompensasi yang dirasa baik oleh karyawan akan meningkatan produktifitas mereka. Ketika sejumlah besar gaji karyawan didasarkan pada tingkat produktivitas mereka, karyawan biasanya akan mengarahkan perhatian mereka terhadap hasil yang diukur dan dihargai (Chien, Lawler, \& Uen 2010), artinya ketika karyawan merasa bahwa kompensasi yang mereka terima sebanding dengan usaha mereka atau mereka merasa dihargai dengan imbalan yang memadai atas produktifitas mereka maka produktifitas mereka akan meningkat.

$\mathrm{H}_{1}$ Terdapat pengaruh positif kompensasi terhadap produktifitas karyawan

\section{Disiplin Kerja}

Disiplin adalah praktik kepatuhan seseorang terhadap aturan atau standar perilaku, dan menghukum mereka ketika mereka tidak melakukannya. Disiplin adalah kualitas untuk dapat berperilaku dan bekerja dengan cara yang terkontrol yang melibatkan mematuhi aturan atau standar tertentu (Collins Dictionary 2019). Disiplin kerja mengarah pada kesadaran dan kesediaan seorang karyawan untuk mematuhi semua peraturan dan norma yang berlaku di perusahaan, baik aturan yang berhubungan dengan waktu kerja, kehadiran, seragam maupun tanggung jawab pekerjaan. Seseorang yang berusaha untuk menunjukkan sikap patuh atau memenuhi peraturan dan norma yang berlaku di dalam perusahaan dapat dikatakan bahwa mereka telah memiliki tingkat disiplin kerja yang baik atau memadai. Lebih lanjut dikatakan bahwa disiplin kerja adalah upaya manajemen perusahaan untuk mengimplementasikan aturan atau regulasi yang harus dipatuhi oleh semua karyawan tanpa pengecualian (Mangkunegara \& Octorend 2015). Studi yang dilakukan Elqdri menyimpulkan bahwa disiplin kerja mempengaruhi produktifitas karyawan(Elqadri et al. 2015).

$\mathrm{H}_{2}$ Terdapat pengaruh positif disiplin kerja terhadap produktifitas karyawan

\section{Motivasi Intrinsik}

Motivasi merupakan arah ketekunan dan sejumlah usaha yang dikeluarkan seseorang untuk mencapai tujuan yang spesifik (Blanchard \& Thacker 2013). Motivasi mengacu pada dorongan baik dari dalam atau luar seseorang yang menimbulkan antusias dan ketekunan untuk mengejar tindakan tertentu. Dorongan yang dimaksud disini merupakan kebutuhan dasar yang ingin dipenuhi oleh karyawan sebagai penghargaan yang diterima atas tindakan mereka yang mengarah pada usaha untuk mencapai tujuan. Penghargaan yang menjadi kebutuhan karyawan terdiri atas penghargaan intrinsik dan ekstrinsik, yang disebut juga dengan motivasi intrinsik dan motivasi ekstrinsik. Motivasi intrinsik merupakan kepuasan yang diterima karyawan dalam proses melakukan tindakan sebagai usaha mencapai tujuan (Daft 2012). Motivasi intrinsik menurut Ambrise dan Kulik yaitu sejauh mana seseorang tertarik pada tugas dan terlibat di dalamnya demi pekerjaan itu sendiri (Li, Wei, Ren, \& Di 2015). Kepuasan dan ketertarikan yang dirasakan karyawan berkaitan dengan pelaksanaan pekerjaannya sehingga memunculkan perasaan nyaman dengan rekan kerja, upaya dan kegigihan untuk berinisiatif, menggunakan keterampilan serta melakukan yang terbaik pada pekerjaannya. Lebih lanjut dikatakan bahwa motivasi 
karyawan mempengaruhi produktifitas dan tugas manajer untuk menjadi bagian dari saluran motivasi yang mengarahkan pada pencapaian tujuan organisasi (Daft 2012). Artinya karyawan dengan motivasi intrinsik dan ekstrinsik akan berusaha mengarahkan tindakan mereka untuk menjadi produktif dalam mencapai tujuan perusahaan.

$\mathrm{H}_{3}$ Terdapat pengaruh positif motivasi intrinsik terhadap produktifitas karyawan

\section{METODE PENELITIAN}

Metode penelitian kausalitas yang digunakan dalam penelitian dimaksudkan untuk mengetahui pengaruh antara Kompensasi, Disiplin Kerja, dan Motivasi Intrinsik terhadap Produktivitas Karyawan departemen Stamping PT. MXX. Jumlah populasi penelitian ini adalah 118 karyawan, dengan teknik sampling jenuh yakni teknik penentuan sampel bila semua anggota populasi digunakan sebagai sampel (Sekaran \& Bougie 2013). Teknik ini digunakan sebab semakin besar jumlah sampel hasil penelitian akan lebih baik untuk menjelaskan populasi penelitian. Data dikumpulkan melalui penyebaran kuesioner secara langsung kepada responden dengan menggunakan 5 skala Likert yakni sangat tidak setuju, tidak setuju, netral, setuju dan sangat setuju.
Populasi dalam penelitian ini yakni seluruh karyawan departemen stamping PT. MXX berjumlah 118 karyawan. Data responden dapat diuraikan sebagai berikut: jumlah populasi didominasi oleh karyawan berjenis kelamin pria sebesar 114 karyawan dengan 4 karyawan wanita, dan usia mereka mayoritas berada pada kisaran 21-30 tahun yakni sebesar 111 karyawan, dan 7 karyawan berusia 41-40 tahun. Masa kerja karyawan dalam populasi ini juga menunjukan bahwa karyawan yang memiliki pengalaman kerja 510 tahun sebesar 102 karyawan, dan 16 karyawan dengan masa kerja 1-5 tahun. Berdasarkan data karakteristik populasi tersebut dapat disimpulkan bahwa mayoritas karyawan pada departemen stamping di PT MXX mayoritas atau lebih dari $85 \%$ adalah karyawan berjenis kelamin pria dengan usia 21-30 tahun dan memiliki pengalaman kerja 5-10 tahun.

Berdasarkan uji validitas dan reliabilitas diperoleh hasil yang menunjukkan bahwa semua instrumen variabel kompensasi, disiplin kerja, motivasi intrinsik dan produktifitas adalah valid dan reliabel. Semua instrumen adalah valid sebab nilai $r$ tabel yakni 0,1809 > nilai $r$ hitung dan semua instrumen variabel adalah reliabel sebab nilai cronbach alpha $>0.6$ berikut adalah tabel pengujian validitas dan reliabilitas:

\section{HASIL}

Tabel 1 Uji Validitas Hasil Uji Validitas Kompensasi (X1)

\begin{tabular}{cccc}
\hline Item Pengukuran & $\mathbf{r}$ hitung & $\mathbf{r}$ tabel & Validitas \\
\hline Gaji tepat waktu & 0,538 & 0,1809 & Valid \\
Gaji memenuhi kebutuhan & 0,496 & 0,1809 & Valid \\
Tunjangan kesehatan & 0,617 & 0,1809 & Valid \\
Tunjangan Hari Raya & 0,682 & 0,1809 & Valid \\
Tunjangan Pensiun & 0,758 & 0,1809 & Valid \\
\hline
\end{tabular}


Tabel 2 Hasil Uji Validitas Disiplin Kerja (X2)

\begin{tabular}{cccc}
\hline Item Pengukuran & $\mathbf{r}$ hitung & $\mathbf{r}$ tabel & Validitas \\
\hline Hadir bekerja lebih awal & 0,619 & 0,1809 & Valid \\
Pulang sesuai waktu bekerja & 0,703 & 0,1809 & Valid \\
Menggunakan waktu istirahat dengan baik & 0,676 & 0,1809 & Valid \\
Menggunakan seragam kerja & 0,513 & 0,1809 & Valid \\
Meminta izin atasan jika tidak masuk kerja & 0,597 & 0,1809 & Valid \\
\hline
\end{tabular}

Tabel 3 Hasil Uji Validitas Motivasi Intrinsik (X3)

\begin{tabular}{cccc}
\hline Item Pengukuran & $\mathbf{r}$ hitung & $\mathbf{r}$ tabel & Validitas \\
\hline Hubungan dengan rekan kerja & 0,697 & 0,1809 & Valid \\
Menyukai tantangan kerja & 0,801 & 0,1809 & Valid \\
Semangat kerja untuk menyelesaikan target & 0,732 & 0,1809 & Valid \\
Memiliki inisiatif memecahkan masalah & 0,753 & 0,1809 & Valid \\
Berusaha menyelesaikan pekerjaan dengan baik & 0,509 & 0,1809 & Valid \\
\hline
\end{tabular}

Tabel 4 Hasil Ujian Validitas Produktivitas Karyawan

\begin{tabular}{cccc}
\hline Item Pengukuran & $\mathrm{r}$ hitung & $\mathrm{r}$ tabel & Validitas \\
\hline Mampu mencapai target output & 0,873 & 0,1809 & Valid \\
Mampu mencapai standar mutu output & 0,893 & 0,1809 & Valid \\
Mampu mencapai target lebih cepat & 0,682 & 0,1809 & Valid \\
\hline
\end{tabular}

Tabel 5 Hasil Uji t

\begin{tabular}{cccc}
\hline Varaibel & $\mathbf{B}$ & $\mathbf{t}$ & $\mathbf{S i g .}$ \\
\hline (Constant) & $-6,774$ & $-3,439$ & 0,001 \\
Kompensasi & 0,597 & 9,728 & 0,000 \\
Disiplin Kerja & 0,229 & 1.705 & 0,091 \\
Motivasi Intrinsik & $-0,034$ & -0.243 & 0,808 \\
\hline
\end{tabular}

Tabel di atas menunjukan, bahwa nilai thitung $>$ ttabel atau $9,728>1,960$ dan nilai sig < nilai alpha atau 0,000 $<0,05$, artinya $\mathrm{H} 1$ diterima yakni terdapat pengaruh kompensasi terhadap produktivitas karyawan. Sebaliknya hasil uji t statistik disiplin kerja menunjukkan bahwa nilai thitung $1.705<1,960$ nilai ttabel dan nilai sig $0,091>0,05$ nilai alpha artinya menolak $\mathrm{H} 2$ yakni disiplin kerja tidak berpengaruh terhadap produktivitas karyawan. Demikian juga pada hasil uji t statistik motivasi intrinsik menunjukkan bahwa nilai thitung $-0,243<$ 1,960 nilai ttabel dan nilai sig $0,808>0,05$ nilai alpha maka $\mathrm{H} 3$ ditolak, artinya motivasi intrinsik tidak berpengaruh terhadap produktivitas karyawan.

\section{PENUTUP}

Hasil penelitian ini menunjukkan bahwa kompensasi memberikan pengaruh terhadap produktitiftas karyawan, temuan ini sejalan dengan studi yang dilakukan (Purbasari \& Septian, 2017), didukung pernyataan bahwa imbalan yang memiliki nilai bersih positif tinggi dapat dan memang mendorong produktivitas dan kinerja karyawan (Samnani \& Singh, 2014) serta kesimpulan yang menyatakan bahwa ketika sejumlah besar gaji karyawan 
didasarkan pada tingkat produktivitas mereka, karyawan biasanya akan mengarahkan perhatian mereka terhadap hasil yang diukur dan dihargai (Chien, Lawler, \& Uen, 2010). Sebaliknya disiplin kerja dan motivasi intrinsik tidak mempengaruhi produktifitas karyawan. Temuan ini menyimpulkan bahwa hanya kompensasi yang memberi pengaruh terhadap produktitiftas karyawan yang mungkin disebabkan oleh dua hal, pertama karakteristik populasi yang didominasi karyawan berjenis kelamin pria dengan usia muda dewasa yakni 21-30 tahun dimana kelompok ini lebih menekankan arti pentingnya kompensasi atau imbalan yang mereka terima untuk memenuhi kebutuhan hidup mereka, baik dalam bentuk gaji yang memadai maupun tunjangan yang mereka terima dapat memuaskan kebutuhan mereka, hal kedua yakni karakteristik pekerjaan pada departemen stamping yang terdiri dari 9 lini proses stamping atau pencetakan bersifat teknologi menengah, alat bantu teknologi menjadi bagian dalam proses pekerjaan mereka, prosedur operasional menjadi bagian pekerjaan rutin mereka sehingga kepuasan internal atau dari dalam diri mereka terkait dengan pekerjaan yang dirasakan seperti inisiatif atau tantangan pelaksanaan tugas dalam rutinitas pekerjaan tidak menjadi motif yang penting sehingga disiplin kerja dan motivasi intrinsik tidak menjadi variabel yang memberi pengaruh terhadap produktifitas mereka.

Penelitian ini masih memiliki keterbatasan pada populasi, yakni hanya menggunakan karyawan departemen stamping PT. MXX wilayah Bekasi, dengan jumlah responden yang juga terbatas yaitu 118 karyawan dikarenakan keterbatasan waktu dan lokasi yang dapat dijangkau. Keterbatasan lainnya pada variabel penelitian yang berfokus pada kompensasi, disiplin kerja dan motivasi intrinsik terhadap produktivitas karyawan, sementara dimungkinkan ada variabel lain yang dapat mempengaruhi produktivitas karyawan. Disarankan untuk menggunakan objek lain dengan populasi yang lebih luas dan menguji variabel lain yang belum diteliti dalam penelitian ini.

\section{REFERENCES:}

Blanchard, N. P., \& Thacker, J. W. 2013. Effective Training:Systems, Strategies, and Practices. (S. Wall, Ed.) (FifthInte). England: Pearson Education Limited. Retrieved from www.pearsoninternationaleditions.com

Chien, M. S., Lawler, J. S., \& Uen, J. F. 2010. Performance-based pay, procedural justice and job performance for R\&D professionals: Evidence from the taiwanese high-tech sector. International Journal of Human Resource Management, 21(12), 2234-2248. https://doi.org/10.1080/09585192.2010.509626

Daft, R. L. 2012. New Era of Management. (M. Acuna \& P. Scott, Eds.) (10th ed.). USA: South-Western, Cengage Learning.

Dulebohn, J. H., \& Werling, S. E. 2007. Compensation research past, present, and future. Human Resource Management Review, 17(2), 191-207. https://doi.org/10.1016/j.hrmr.2007.03.002

Elqadri, Z. M., Wardoyo, D. T. W., \& -, P. 2015. The Influence of Motivation and Discipline Work against Employee Work Productivity Tona'an Markets. Review of European Studies, 7(12). https://doi.org/10.5539/res.v7n12p59

Li, Y., Wei, F., Ren, S., \& Di, Y. 2015. Locus of control, psychological empowerment and intrinsic motivation relation to performance. Journal of Managerial Psychology, 30(4), 422-438. https://doi.org/10.1108/JMP-10-20120318

Makki, A., \& Abid, M. 2017. Influence of Intrinsic and Extrinsic Motivation on Employee's Task Performance. Studies in Asian Social Science, 4(1), 38. https://doi.org/10.5430/sass.v4n1p38

Mangkunegara, A. P., \& Octorend, T. R. 2015. Effect of Work Discipline, Work Motivation and Job Satisfaction on 
Employee Organizational Commitment in the Company (Case Study in PT. Dada Indonesia). Universal Journal of Management, 3(8), 318-328. https://doi.org/10.13189/ujm.2015.030803

Purbasari, R. N., \& Septian, T. A. 2017. Factors Influencing on Employee Performance of Production Department on the Manufacturing Food Industry in Indonesia. Polish Journal of Management Studies, 16(2), 233-242. https://doi.org/10.17512/pjms.2017.16.2.20

Robbins, \& Coulter, M. 2009. Management. (C. Fernandes \& E. Davis, Eds.) (Tenth-Inte). New Jersey: Pearson Education Limited.

Samnani, A. K., \& Singh, P. 2014. Performance-enhancing compensation practices and employee productivity: The role of workplace bullying. Human Resource Management Review, 24(1), 5-16. https://doi.org/10.1016/j.hrmr.2013.08.013

Sekaran, U., \& Bougie, R. 2013. Research Methods for Business (Sixth Edit). United Kingdom: John Wiley \& Sons Ltd.

Sink, D. S., Tuttle, T. C., \& Devries, S. J. 1984. Productivity measurement and evaluation: What is available? National Productivity Review, 3(3), 265-287. https://doi.org/10.1002/npr.4040030305 
